\title{
Laboratory Findings, Vaginal Cytology and Histopathology in Bitches with Cystic Endometrial Hyperplasia - Pyometra Complex
}

\author{
Martin Llazani, Alketa Qoku, and Luljeta Dhaskali
}

\section{ABSTRACT}

Cystic Endometrial Hyperplasia -Pyometra complex, a common pathological condition of uterus in bitches, it is attributed hormonal and bacteriological causes. It is studied in $\mathbf{1 0}$ bitches of cross and pure bred and aged from 1-13 years. In this study, the average age of animals was $8.33 \pm 1$ year. Hematological and biochemical lab findings were evaluated in bitches with or without vaginal discharge. Lab findings were leukocytosis, neutrophilia and normocytic, normocromic anemia. Biochemical results shown increased of ALT and ALKP and a moderate of BUN. An increased number of parabasal and intermediate cells were detected in vaginal cytology. Histopathologic diagnosis confirmed thickness of uteri wall, a lot of cystic glands of it and the pus presented in lumen of uterus and its horns.

The purposes of this study were that through different techniques to diagnose earlier Cystic Endometrial Hyperplasia - Pyometra complex in bitches, in order to welfare of animals.

Keywords: Bitches, CEH-Pyometra Complex, cytology, histopathology.
Published Online: June 08, 2021

ISSN: $2684-5199$

DOI: $10.24018 /$ ejbio.2021.2.3.200

\section{Martin Llazani*}

Vet Hospital, Tirana, Albania. (e-mail: llazanimartin@yahoo.com) Alketa Qoku

Agricultural University of Tirana, Faculty of Veterinary Medicine, Tirana, Albania. (e-mail: aqoku@ubt.edu.al) Luljeta Dhaskali

Agricultural University of Tirana, Faculty of Veterinary Medicine, Tirana, Albania. (e-mail: 1.dhaskali@ubt.edu.al)

*Corresponding Author

\section{INTRODUCTION}

Cystic Endometrial Hyperplasia (CEH) -Pyometra complex is a pathological condition affecting the uterus of bitches, and queens [14]. A feature of CEH -pyometra complex is presence of pus in horns of uterus, caused by different bacteria. It has been described to be prevalent in middle-aged and older bitches, especially nulliparous ones [7], [18], [3]. The most important clinical signs are anorexia, vomiting, vaginal discharge, pyrexia, etc. Vaginal discharge could be from mucopurulent to sanguineous ones if the cervix is open [18], [3]. In bitches with pyometra the leukocyte concentration in blood is elevated to 15 000-60 $000 / \mathrm{mm}^{3}$ [5]. Upon histological examination uterus and its horns present large cystic endometrial glands and endometrial thickness, a lot of inflammatory cells into the glandular and uterine luminal areas and bacterial colonies [2].

The diagnosis of $\mathrm{CEH}$ - pyometra complex based on case history, physical examination, lab findings, ultrasonography and cytology of the vaginal discharge could be verified by histopathological examination of the uterine tissue [15].

Therefore, a better understanding of the mechanisms involved in the pathogenesis of CEH-pyometra complex in dogs and, so, for the accurate diagnosis of the disease [9].
This study was carried out to use laboratory, cytologic and pathologic findings to diagnose $\mathrm{CEH}$ - pyometra complex in bitches naturally affected [6].

\section{MATERIALS AND Methods}

A total of 10 bitches from pure and cross breeds were included in the study. Animals were presented because of clinical symptoms of pyometra. The mean $( \pm \mathrm{SE})$ age of the bitches was $8.33 \pm 1$ year (range 1-13 years). They were presented on Pet hospital and Lab of Pathology at Agricultural University of Tirana, Faculty of Veterinary Medicine, Tirana, Albania in period of March 2018 September 2019. History was taken and clinical examinations were performed.

Blood samples were taken from all animals for haematology (leucocyte and its formula, erythrocytes, and some of its findings (NIHON KOHDEN, Celtaco) and biochemistry results like as urea, alkaline phosphatase, and alanine amino transferase (IDEXX Catalyst One) were performed.

Vaginal cytology was used to determine the types of epithelial cells of vagina. A cotton tip was inserted into the vagina and was pressed to the surface of the vagina lumen. It was then withdrawn and rolled on the surface of a glass slide, which drained in air and stained with Diff-Quick stain. 
A nuclear, superficial, intermediate and parabasal cells were evaluated. A total of 100 cells were counted per slide.

After examination, ovariohysterectomy, under general anaesthesia, using routine surgical techniques was performed in all bitches. The tissue samples taken from different part of horns were fixed in $10 \%$ formaldehyde, embedded in paraffin, and cut in $4 \mu \mathrm{m}$ sections, stained with Haematoxylin - Eosin, and examined with a light microscope for histopathological changes.

\section{RESUlTS AND DISCUSSION}

In the haematological and blood biochemical examinations, there are many alterations that can be induced

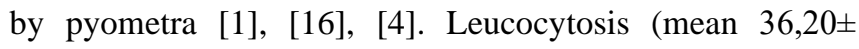
2,27 ), with neutrophilia and left shift are characteristic findings in pyometra together with normocytic, normochromic anaemia, were found in this study. This normocytic, normochromic anaemia is thought to reflect the chronicity of the disease [15].

Hematologic results are given in Table I.

TABLE I: HeMATOLOGICAL RESUltS IN BITCHES WITH CEH-PyOMETRA

\begin{tabular}{|c|c|c|c|c|c|c|c|}
\hline \multicolumn{8}{|c|}{ COMPLEX } \\
\hline & $\begin{array}{c}\text { WBC } \\
10^{3} / \mathrm{mcL} \\
6.0-17.0\end{array}$ & $\begin{array}{c}\text { RBC } \\
10^{6} / \mathrm{mcL} \\
5.50-8.50\end{array}$ & $\begin{array}{c}\text { HGB } \\
\mathrm{g} / \mathrm{dL} \\
12.0-18.0\end{array}$ & $\begin{array}{c}\mathrm{LY} \\
\%\end{array}$ & $\begin{array}{c}\mathrm{MO} \\
\%\end{array}$ & $\begin{array}{c}\text { EO } \\
\%\end{array}$ & $\begin{array}{c}\text { GR } \\
\%\end{array}$ \\
\hline & 32,1 & 4,12 & 9 & 20,6 & 3,7 & 1,6 & 78,9 \\
\hline & 25,5 & 5,47 & 12,8 & 20,6 & 4,1 & 1 & 74,3 \\
\hline & 46,6 & 7,3 & 16,9 & 12,8 & 3,6 & 2,4 & 81,2 \\
\hline & 19,8 & 4,65 & 11 & 19,3 & 4,7 & 2,3 & 73,7 \\
\hline & 44,3 & 5,9 & 14,1 & 13,1 & 5,1 & 0,3 & 81,5 \\
\hline & 39,8 & 7,41 & 20,1 & 15,1 & 3,4 & 0,7 & 80,8 \\
\hline & 58,3 & 6,69 & 16,3 & 34,5 & 10,1 & 0,8 & 54,6 \\
\hline & Over & 4,19 & 11,6 & & & & \\
\hline & 23,7 & 7,03 & 17,2 & 12,3 & 3,9 & 0,9 & 82,9 \\
\hline Mean & 36,2 & 5,36 & 13,36 & 18,4 & 4.41 & 3,13 & 74,7 \\
\hline Medin & 35,95 & 5,47 & 12,8 & 17,2 & 4 & 0,95 & 78,3 \\
\hline SE & $-2,27$ & $-0,24$ & $-2,22$ & $-1,7$ & 0,24 & 0,42 & $-8,01$ \\
\hline SD & 13,77 & 1,49 & 3,77 & 7,92 & 2,43 & 4,51 & 8,7 \\
\hline $\mathrm{t}$-test & 9 & 0,92 & 2,34 & 5,17 & 1,59 & 2,95 & 5,68 \\
\hline
\end{tabular}

A. Biochemical Result

TABLE II: BIOCHEMICAL RESULTS IN BITCHES CEH-PYOMETRA COMPLEX

\begin{tabular}{|c|c|c|c|c|c|c|}
\hline $\begin{array}{c}\text { no. dog } \\
10\end{array}$ & $\begin{array}{c}\text { CREA } \\
0.5-1.8 \\
\mathrm{mg} / \mathrm{dl}\end{array}$ & $\begin{array}{l}\text { BUN 7.0- } \\
27 \mathrm{mg} / \mathrm{dl}\end{array}$ & $\begin{array}{c}\mathrm{TP} \\
5.2-8.2 \\
\text { g/dl }\end{array}$ & $\begin{array}{l}\text { ALT 10- } \\
12.5 \mathrm{U} / \mathrm{L}\end{array}$ & $\begin{array}{c}\text { ALKP } \\
23-214 \\
\text { U/1 }\end{array}$ & $\begin{array}{c}\text { Age of } \\
\text { bitch }\end{array}$ \\
\hline & 3,3 & 130 & 6,5 & 0,69 & 64 & 13 \\
\hline & 0,5 & 6 & 5,5 & 43 & 57 & 10 \\
\hline & 1 & 23 & 7,3 & 292 & 1748 & 12 \\
\hline & 0,4 & 29 & 5,5 & 87 & 135 & 9 \\
\hline & 1.02 & 69 & 4 & 782 & 227 & 3 \\
\hline & 0,6 & 7 & 7,4 & 55 & 60 & 8 \\
\hline & 1,3 & 12 & 6,5 & 53 & 21 & 5 \\
\hline & 0,4 & 7 & 7,3 & 60 & 21 & 5 \\
\hline & 0,5 & 26 & 6,9 & 37 & 151 & 9 \\
\hline & 1 & 24 & 7 & 98 & 193 & 10 \\
\hline \multicolumn{7}{|l|}{$\mathrm{N}$} \\
\hline Mean & 1,08 & 33,78 & 6,49 & 157,85 & 282,44 & 8,33 \\
\hline Median & 0,6 & 23,5 & 6,7 & 57,5 & 99,5 & 9 \\
\hline SE & 4 & -1 & -1 & -1 & -1 & -1 \\
\hline $\begin{array}{l}\text { Stand. } \\
\text { Deviat. }\end{array}$ & 0,98 & 40,26 & 1,15 & 47,15 & 49,19 & 3,15 \\
\hline $\mathrm{t}$-test & 0,75 & 28,80 & 0,82 & 176,80 & 392,87 & 2,26 \\
\hline
\end{tabular}

The most important serum biochemistry finding is high level of alkaline phosphatase, $(157.85 \pm 4)$ in our study. It is referred in approximately $50-75 \%$ of cases [8], [17]. It could be seen high level of serum alkaline phosphatase concentrations as well as $(282.44 \pm 1)$. These changes reflect hepato-cellular damage in response to toxemia or diminished hepatic circulation due to dehydration [11]. The most commonly biochemical results reported include elevated alkaline phosphatase, alanine transaminase activities, and blood urea nitrogen (BUN) [8], [7], [17]. Biochemical results are given in Table II.

\section{B. Vaginal Cytology}

Vaginal cytology in bitches with open-cervix pyometra have typically demonstrated excessive numbers of degenerate neutrophils (Fig. 1) and a highly number of parabasal cells (Results referred before (Fig. 2), [13]. Meanwhile, vaginal cytology in patients with completely closed-cervix pyometra could be used and the epithelial cells find there are parabasal cells. On the other hand, intermediate cells are decreased in this pathology. Cystic endometrial hyperplasia $(\mathrm{CEH})$ - pyometra complex in the bitch is a diastral syndrome, supposed to be caused by hormonal disturbances and changes in endometrial steroid hormone receptor levels [10], [3]. It is manifested with type' changes of epithelial cells.

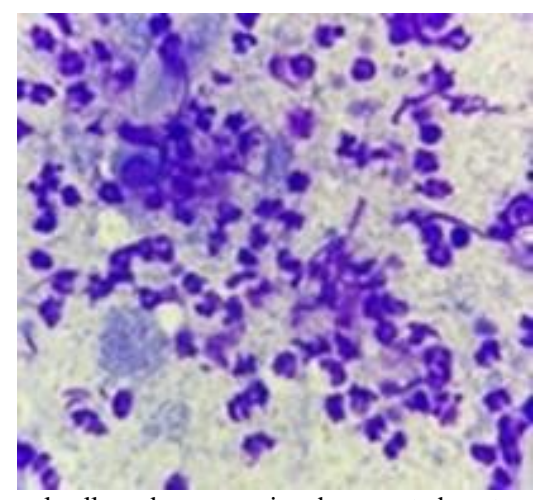

Fig. 1. Parabasal cells and an excessive degenerated neutrophil in vaginal cytology of a bitch with CEH-Pyometra complex.

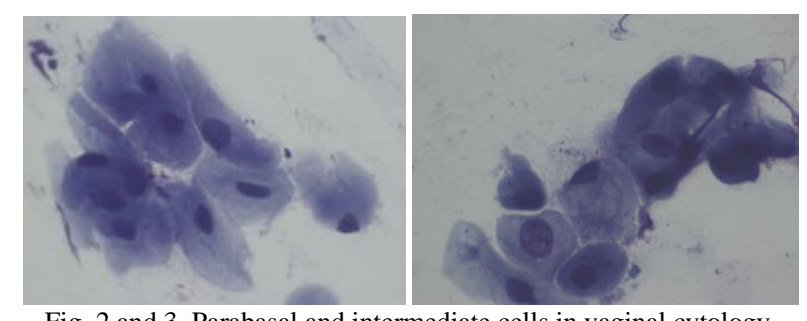

Fig. 2 and 3. Parabasal and intermediate cells in vaginal cytology.

\section{Histopathological Examination}

The bitches with CEH-Pyometra complex showed these different histological features. There are enlarged uterine glands in size and number, and crypts filled with inflammatory cells. Connective tissue was invaded by leukocyte (neutrophils) and plasma cells and (Fig. 4) and it can see vascular congestion (Fig. 4). The surface epithelium was composed of columnar cells with foamy cytoplasm (Fig. 5). These findings are referred from other authors [10], [7]. Microscopically, the most significant feature is the remarkable endometrial hyperplasia and enlarged cystic glands, in almost all cases Fig. 6). The histologic changes due to infection vary with the bacterial cause and time of infection [12]. 


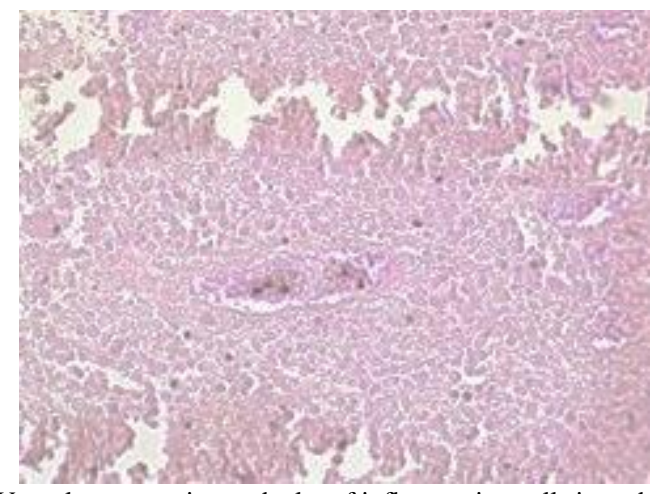

Fig. 4. Vascular congestion and a lot of inflammation cells in endometrium of a bitch with CEH-pyometra complex.

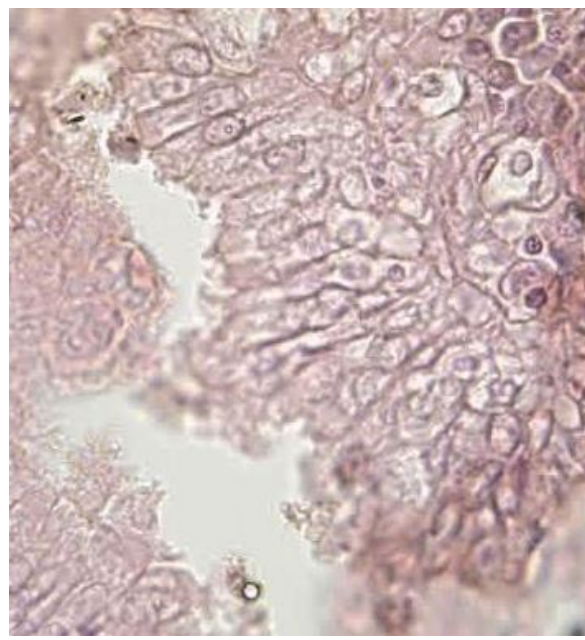

Fig. 5. Epithelial cells of endometrium. They are cylindric in form and cytoplasm is a foamy appearance.

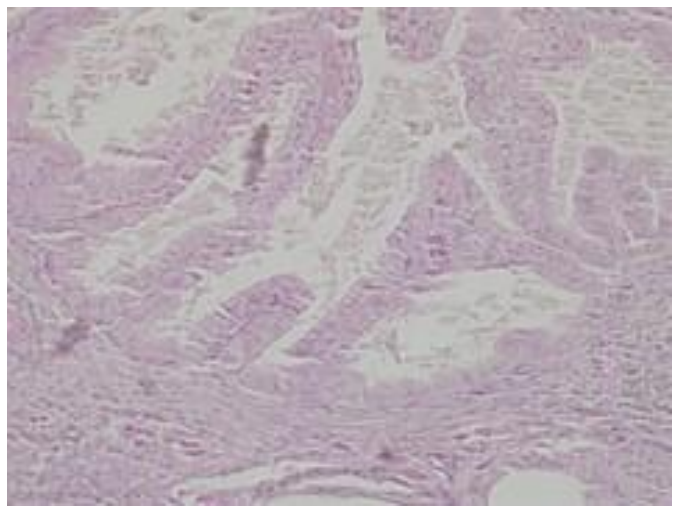

Fig. 6. A lot of enlarged cystic glands, a typical feature of CEH-Pyometra complex.

\section{CONCLUSION}

Leucocytosis, with neutrophilia and left shift are characteristic findings in pyometra together with normocytic, normochromic anaemia. Elevated alkaline phosphatase, alanine transaminase activities, and blood urea nitrogen (BUN) were the most commonly biochemical results found in the study.

Cystic endometrial hyperplasia $(\mathrm{CEH})$ - pyometra complex in the bitch is a diestral syndrome, supposed to be caused by hormonal disbalance and under the role of bacteria which cause the change of the type of epithelial cells. Parabasal cells are more evident in smears in vaginal cytology of affected animals.

Microscopically, the most significant features are the evident endometrial hyperplasia and enlarged cystic glands of uterus. Histopathological diagnosis is the "gold standard" in the diagnosis of it.

This study was carried out to use some different techniques to diagnose earlier $\mathrm{CEH}$ - pyometra complex in bitches naturally affected, in order to a welfare of pets.

\section{REFERENCES}

[1] B. A., Fransson. "Systemic Inflammatory Response in Canine Pyometra". Doctoral Thesis. Acta Universitatis Agriculturae Sueciae, Veterinaria 161, pp. 48. 2003.

[2] B. Kempisty, D. Bukowska, M. Wozna, H. Piotrowska, M. Jackowska, A. Zuraw, S. Ciesiolka, P. Antosik, H. Maryniak, E. Ociepa, Sz. Porowski, K.P. Brussow, J.M. Jaskowski, M. Nowicki 2013. "Endometritis and pyometra in bitches: A review". Veterinarni Medicina, vol. 58 (6), pp. 289-297, 2013.

[3] B. L. Hamm, J. Dennis. "Canine pyometra. Early recognition and diagnosis". Veterinary Medicine. May 01, 2012.

[4] B. Maddens, R. Heiene, P. Smets, M. Svensson, L. Aresu, J. van der Lugt, S. Daminet, E. Meyer. "Evaluation of kidney injury in dogs with pyometra based on proteinuria, renal histomorphology, and urinary biomarkers". J Vet Intern Med, vol. 25, pp. 1075-1083, 2011.

[5] Bigliardi and Pamigiani. "Ultrasonography and Cystic HyperplasiaPyometra Complex in the Bitch". Reproduction in Domestic Animals, 2004 Blackwell Verlag, Berlin, 2004, ISSN 0936-6768.

[6] C. Dow. "Experimental reproduction of cystic endometrial-pyometra complex in the bitch". J Pathol Bacteriol, vol. 78: pp. 267-79, 1959.

[7] E. C. Feldman, R. W. Nelson. "Canine and Feline Endocrinology and Reproduction”, Ed Pedersen, Saunders, Philadelphia, pp. 525-548, 1987.

[8] E. C. Feldman, R. W. Nelson. "Cystic endometrial hyperplasia/pyometra complex". In: Canine and feline endocrinology and reproduction. 3rd ed. St. Louis, Mo: Saunders, pp. 852-867, 2004.

[9] G. A. L. Veiga, R. H. Miziara, D. Souza Ramos Angrimani, P. Carvalho Papa, B. Cogliati, C. Infantosi Vannucchi. "Cystic endometrial hyperplasia-pyometra syndrome in bitches: identification of hemodynamic, inflammatory, and cell proliferation change". Biology of Reproduction, vol. 96(1): pp. 58-69, 2017.

[10] H. De Bosschere, R. Ducatelle, H. Vermeirsch, W. Van Den Broeck, Coryn M. "Cystic endometrial hyperplasia-pyometra complex in the bitch: should the two entities be disconnected?" Theriogenology, vol. 55: pp. 1509-19, 2001.

[11] J. Verstegen, G. Dhaliwal, K. Verstegen-Onclin. "Mucometra, cystic endometrial hyperplasia, and pyometra in the bitch: Advances in treatment and assessment of future reproductive success". Theriogenology, vol. 70:364-374, 2008.

[12] K. V. F. Jubb, P. C. Kennedy, R. B. Miller. Pathology of Domestic Animals, Eds Jubb, Kennedy \& Palmer, 4th edn, 2003. pp382-384, Academic Press, San Diego.

[13] M. Llazani, A. Qoku, L.Dhaskali. Ultrasonographic diagnosis of pyometra on bitches: a preliminary study. Veterinary Medicine 2021, May 26-27, 2021, Dublin, Ireland.

[14] M. Woźna-Wysocka, M. Rybska, B. Błaszak, B. M. Jaśkowski, M. Kulus. "Morphological Markers of Pathological Changes in Bitches Endometrium Affected by a Cystic Endometrial Hyperplasia Pyometra Complex (CEH-P)". 2020. DOI:10.21203/re.3.rs-26656/v3.

[15] R Hagman. "Clinical and Molecular Characteristics of Pyometra in Female Dogs" Reprod Dom Anim 47, vol. 6 323-325, 2012. doi: 10.1111/rda.12031 ISSN 0936-6768).

[16] R. Hagman, H. Kindahl, A. S. Lagerstedt. "Pyometra in bitches induces elevated plasma endotoxin and prostaglandin F2a metabolite levels". Acta Vet Scand. vol. 47: pp. 55. 2006.

[17] R. W. Nelson, E. C. Feldman. "Pyometra". Vet Clin N Am Small Anim Pract, vol. 16: pp. 561. (1986). doi: 10.1016/s0195-5616(86)50061-9.

[18] S. D. Johnston, M. V. R. Kustritz, P. N. S. Olson. "Canine and Feline”. Theriogenology, Ed Kersey, pp 463-471, Saunders, Philadelphia, 2001. 